Portland State University

PDXScholar

\title{
The Value of Midterm Student Feedback in Cross- Disciplinary Graduate Programs
}

\author{
G.L.A. Harris \\ Portland State University \\ Dannelle D. Stevens \\ Portland State University, bgsd@pdx.edu
}

Follow this and additional works at: https://pdxscholar.library.pdx.edu/edu_fac

Part of the Educational Assessment, Evaluation, and Research Commons, and the Higher Education and Teaching Commons

Let us know how access to this document benefits you.

\section{Citation Details}

Harris, G. L. \& Stevens, D. D. (2013). The value of midterm student feedback in cross-disciplinary graduate programs. Journal of Public Administration Education, 19(3) 537-558.

This Article is brought to you for free and open access. It has been accepted for inclusion in Education Faculty Publications and Presentations by an authorized administrator of PDXScholar. Please contact us if we can make this document more accessible: pdxscholar@pdx.edu. 


\title{
The Value of Midterm Student Feedback in Cross-Disciplinary Graduate Programs
}

\author{
G. L. A. Harris \\ Mark O. Hatfield School of Government \\ Portland State University
}

Dannelle D. Stevens

Graduate School of Education

Portland State University

\begin{abstract}
End-of-course student evaluations are frequently used to evaluate university faculty teaching. However, employing midterm student feedback has been found to be instrumental in informing faculty about instructional quality and improving student learning outcomes. This study examined and compared the effects on classroom instruction of using a midterm student feedback (MSF) survey in the graduate courses of two faculty, an untenured professor in public administration and a full professor in education. The researchers gathered data from 122 students over two years for three courses in 6 classes -4 in public administration, 2 in education. Results indicate that midterm student feedback offered insight for faculty at both levels. In addition, when faculty make instructional changes based on MSF data, students' responses improve. Implications for future research are also discussed.
\end{abstract}

Keywords: midterm student feedback, end-of-course evaluations, cross-disciplinary, graduate programs

While much has been debated about the kind of feedback that facilitates student learning (Campbell, Steiner \& Werdes, 2005; Giles \& Pascoe, 2004; Kember, Leung, \& Kwan, 2002; Murray, 1987; Richardson 2005; Whittington, 2001), all would agree that students benefit from some feedback (Gallagher 2000; Hattie \& Timperley, 2007; Hobson \& Talbot 2001; Sojka, Gupta \& Deeter-Schmelz, 2002). But what about the faculty? When do faculty members receive feedback 
about their teaching? It is customary for faculty to receive student evaluations at the end of the course (Giles \& Pascoe, 2004, Keutzer, 1993). However, there are some questions about the value of these end-of-course evaluations in making teaching improvements (Gray \& Bergmann, 2003, Senior 2000; Wolfer \& McKnown Johnson, 2003). Therefore, faculty members are employing other options like midterm student feedback (MSF) to make corrections to improve a course before the end of the term (Austin \& Austin; 2002; Davis Bullock, 2003; Diamond, 2004; Keutzer, 1993; Overall \& Marsh, 1979).

The purpose of this study was to examine student midterm survey results in three courses over two successive terms (six classes in total) and within two different disciplines (public administration and education). Two faculty members conducted this research: one faculty was untenured (at the time) from a School of Government within a larger college, while the other faculty member was a tenured full professor in a Graduate School of Education at the same university. Neither one of us as faculty had used midterm student feedback (MSF) before, and we were both interested in collaborating on the administration and analysis of the results of this type of survey. Given the brevity of a quarter system and the time that it takes for cross-discipline collaboration, we administered the survey in one term for specific courses. Then, the next time we taught the same courses, we implemented the student recommendations from the survey of the first course and re-administered a second midterm student survey when the same course was subsequently taught. We know this is not the typical approach to using midterm student surveys and realize that this type of administration has limitations. In doing so, we addressed the following questions: First, "How does a different group of students in the same course respond to instructional changes based on the midterm survey results from a previous term?" And second, "What kind of course corrections were made based on the MSF results, and how do these align with effective instructional practices?"

\section{LITERATURE REVIEW}

Hattie and Timperley (2007), in their literature review on feedback, describe feedback as a powerful tool that can positively and negatively affect learning and achievement. The teacher functions as an agent who bestows information upon the student and provides feedback as a "consequence" of the student's performance (Hattie \& Timperley, 2007, p. 81). Others, like Gallagher (2000) and Hobson and Talbot (2001), regard student teaching evaluations as an integral mechanism for measuring effective instruction. Accordingly, these student evaluations of teaching effectiveness (SETE) constitute a formative approach for students to inform faculty about their teaching and in turn for faculty to use such information to improve instruction (Hobson \& Talbot, 2001). However, the degree to which the student evaluation is accepted and acted upon depends solely on the faculty. The more readily the faculty member accepts the student evaluation as such, the more likely the faculty member will view the evaluation as instrumental to teaching 
(Gallagher, 2000) and to improving student learning outcomes. In other words, student evaluations should not be summarily dismissed by faculty as either unimportant or questionable in nature (Gallagher, 2000; Murkison \& Stapleton, 2001) because, in the end, both faculty and students can benefit from their use. Yet, despite the perceived benefits of student evaluations, there are also some accompanying concerns.

The research on the value of the end-of-course evaluations is mixed. Typically, the administration of student evaluations comes at the end of a term or semester of teaching a course (Giles \& Pascoe, 2004; Keutzer, 1993). While these evaluations inform faculty about their teaching performance, faculty cannot make timely adjustments until the next time the course is taught. Other researchers have questioned the value of the end-of-course feedback as ineffective (Gray \& Bergmann, 2003) in that better measures of student performance are available. Baker (1992) asserts that obtaining feedback is wasteful and results in grade inflation. Furthermore, Armstrong (1998) notes that end-of-term evaluations shift the responsibility for learning from the students to the faculty. A more recent study by Langbein (2005) considers that student evaluation of the teaching tool is not only a faulty measure of teaching performance, but that the implications for this measure can be unintentionally negative. Moore (2009) goes even further and maintains that student evaluations are notorious for problems that include manipulation, are not linked to student learning outcomes, provide students with leverage over faculty, and unnecessarily induce stress on the faculty being evaluated. Similarly, traditional end-of-course measures continue to be widely used even though they are considered by some to be "crude judgments of instructional effectiveness" (Abrami, d'Apollina, \& Rosenfeld, 2007; Wolfer \& McKnown Johnson, 2003, p.117).

Like Moore (2009), some researchers question the reliability and validity of end-of-course evaluations, because such results may be strongly influenced by confounding variables like class size, faculty likability, gender, and type of courseelective or required (Hobson \& Talbot, 2001; Langbein, 1994; Marsh \& Roche, 1997). Moreover, Slocombe, Miller, and Hite (2011) found that likability is a moderating variable that influenced students' end-of-course evaluations. In essence, the more that students like the instructor, the greater the likelihood of favorable end-of-course evaluations for that course and thus for the faculty teaching the course. Smaller class size, or the number of students rating a course, for example, is said to more positively skew the reliability of student evaluations (Marsh \& Roche, 1997). According to Langbein (1994), every incremental increase of 10 students in a course decreases the students' evaluations of teachers by 0.06 . In some cases, same-gender instructors increase the probability that same-gender students will score them more favorably (Basow, 1998; Langbein, 1994; Wolfer \& McKnown Johnson, 2003). So, a course that is taught by a female and that is predominantly female in composition may result in higher evaluations, particularly for those who are viewed as caring (Langbein, 1994; Sojka et al., 2002). Yet, just as these results can be validated, in the same vein, they can be refuted by other studies as well. 
Class size, faculty gender, and elective versus required courses can be confounding variables as well. While smaller classes tend to yield more positive student evaluations for faculty, and the converse is true for larger class sizes, the relationship between the variables may not be as direct (Langbein, 1994). More important, the evaluation scores may not necessarily indicate teaching quality at all. In some cases, the relationship between class size and student evaluations is curvilinear (Algozzine et al., 2001), because some large classes are positively rated by students. As Campbell and colleagues (2005) are quick to point out, however, that class size is a variable beyond the faculty's control. For gender, Centra and Gaubatz (2000) show that few gender preferences and more positive ratings for female faculty are a reflection of students' interests in particular subjects of study. Yet, others like Heine and Maddox (2009) speculated that these results may be a function of the female students appearing to take the course evaluation process more seriously than their male counterparts, who perceived the exercise cynically. And, according to Langbein (1994), this positive result may also be indicative of expected grades by students as well as the amount of time students invested in the course outside the classroom. Others, like Foote, Harmon, and Mayo (2003), found no such differences in evaluations by female students relative to male students when the teaching faculty was female. While elective courses tend to generate more positive student evaluations (Marsh \& Roche, 1997), some data suggest that more challenging courses, or those purported and more likely than not to be required or core courses, can also generate positive student evaluations (Campbell et al., 2005). Nevertheess, end-of-course evaluations on more difficult courses tend to yield disproportionately negative ratings for instructors (Slocombe et al., 2011; Thorton, Adams, \& Sepehri, 2010). In fact, courses that are challenging are rated significantly above those that are not (Whittington, 2001) or do not always produce lower ratings than the less challenging courses (Chen \& Chen, 2010). However, faculty are penalized with lower ratings when students believe that the course workload is disproportionate and/or when they receive lower than expected grades (Campbell et al., 2005). But, even if students give such courses lower ratings, doing so may not indicate bias (McKeachie, 1997). Instead, low student evaluations may simply be evidence of poor teaching (Whittington, 2001).

Part of the challenge surrounding the debate about using end-of-course student evaluations is that there is no consensus on what constitutes good teaching and how such teaching can be improved (Germain \& Scandura, 2005). Langbein's (1994) study concluded that it is difficult to ascertain what variables are measuring teaching effectiveness. Why? Because student evaluations reflect various factors, including (a) which faculty members are the most popular, (b) which faculty are truly effective teachers, and (c) the faculty's age and gender. More important, higher student evaluations may not necessarily mean effective teaching. The absence of a uniform definition of good teaching and the inconsistency in methodologies used to discern teaching as a construct compound the problem 
(Germain \& Scandura, 2005). Besides, those in the discipline cannot agree on how the results of teaching should be measured (Abrami et al., 2007). Should teaching be measured by what it generates, how teachers perform, or by student learning outcomes? More recent studies point to divergent ways of measuring similar data, such as the following: Students believed that faculty who are evaluated become better teachers (Clayson \& Haley, 2011); the more objective the learning measures become, the less correlation there is between student evaluations and learning outcomes (Clayson, 2009); while less experienced faculty were rewarded with higher student evaluations for introductory courses (Carrell \& West, 2010), more experienced faculty were penalized for stringent grading even though lower grades resulted in "deeper learning" (p. 429) that caused students to perform better in subsequent courses (Carrell \& West, 2010; Johnson, 2003); and lower student evaluations may cause faculty to reduce experimentation with new techniques and even the abandonment of techniques that they believe to be the most beneficial to students (Armstrong, 1998; Lang \& Kersting, 2006). Still, the most effective teachers are thought to be those who inspire students (Langbein, 1994), provide the most challenging work (Campbell et al., 2005; Whittington, 2001), and value student feedback to improve their teaching (Yao \& Grady, 2006) through the use of well-designed student evaluations to measure teaching effectiveness (Hobson \& Talbot, 2001).

\section{The Benefits of Midterm Student Feedback}

These genuine research-based philosophical differences about the value of the end-of-course student evaluation provide the rationale for using mid-term or midsemester student feedback (MSF). Faculty have used midterm student feedback surveys in conjunction with the end-of-course student evaluation to make timely midcourse corrections to foster better student learning outcomes and increase teaching effectiveness (Senior, 2000; Keutzer, 1993; Holt \& Moore, 1992) while producing more favorable end-of-course student evaluations (Kember et al., 2002). The literature has been overwhelmingly positive about the benefits of midterm student feedback. Earlier studies such as those by Friedlander (1978) and Cohen (1980) attribute improved end-of-course ratings to be at least one third of one standard deviation higher than that of control groups, due to the intervention of midterm student feedback.

A more recent study by Kember et al. (2002) confirmed that while this may be the case, few studies have been conducted on the effects of midterm student feedback beyond the three- or four-year period. In a study over 13 years, however, Marsh and Hocevar (1991) showed sustained improvement by individual faculty members consistently using MSF. Cohen's (1980) research demonstrated that faculty who solicited midterm student feedback improved their end-of-course ratings from the 50th percentile to the 58th percentile while those who administered the instrument along with consultation about the results increased their end-of-term ratings to the 75 th percentile. As well, the online administration of 
midterm student feedback can potentially generate even higher ratings for faculty given the ease of use, the associated anonymity (Austin \& Austin, 2002; Ballantyne, 2000), and the timely receipt by faculty for quick response to students (Davis Bullock, 2003; Kulik, 2001; Sheehan, 2001).

Overall and Marsh (1979) found that the use of midterm student feedback resulted in multiple benefits for faculty: (a) Students rated faculty more highly, (b) faculty were motivated to modify instruction, (c) faculty could make changes in the same course before the end of the term, and (d) faculty realized a positive correlation between the midterm student feedback and student learning outcomes. These results in turn can help forge an environment between faculty and students that is conducive to learning and growth. According to Keutzer (1993), this kind of environment makes students feel empowered because the feedback goes directly to the faculty, and specific changes are based on their assessment. MSF benefits all involved (Austin \& Austin, 2002; Diamond, 2004; Holt \& Moore, 1992; Keutzer, 1993; Senior, 2000; Sojka et al., 2002).

We collaborated on the design, implementation, and analyses of the same midterm student feedback survey administered in a total of six of our classes across our two different disciplines: public administration and teacher education.

\section{Methodology}

In three courses over two successive terms, we collaborated on improving our classroom instruction through the analysis of MSF. We are from a School of Government (public administration) within a larger college and a Graduate School of Education (teacher education). One of us is untenured (at the time) and the other is a tenured faculty member, respectively. Both schools are housed in a large urban public university located in the northwestern region of the United States. We gathered the MSF survey data from three courses, two in public administration and one from teacher education. We repeated the survey for a second time in each course when the same course was taught again. Therefore, we have MSF data from six classes across two different terms in two disciplines, public administration and education.

Typically, faculty implement changes in a course during the term when they collect the MSF data. Our university is on the quarter system; courses are 10 weeks long and there is one finals week, for a total of 11 weeks per term. This means a very quick turnaround for the MSF feedback. In this study, we collaborated across our disciplines and levels of experience to garner the greatest benefits from using MSF to improve instruction. The surveys were administered in Phase I (two in Winter term for public administration, one in Winter term for education). Then, we analyzed the survey results in Phase II. We made instructional changes based on the survey results in the courses during Phase III and administered another MSF the second time we taught each course. During Phase IV, we analyzed the results of the second administration of the MSF survey. 
From this study, we focused on how the results from the MSF survey can be used to improve classroom instruction regardless of discipline, even in a subsequent offering of the course. Results indicated that the MSF survey addressed specific ways that we can improve instruction. Since we met 15 times over two years to discuss and analyze the results of the MSF surveys, we discovered similar and different views and knowledge levels that each of us as faculty held about college teaching. We both sought to engage students in discussion and group work. Dr. H., the untenured faculty from public administration, had the need for more lecture. We were both concerned with improving student writing as well. Yet, Dr. S., the tenured faculty from teacher education, had students submit drafts early in the term, while the untenured faculty member initially did not do so until following the midterm.

\section{Participants}

Graduate students who were enrolled in the three courses during Phase I, and a second set of graduate students enrolled in the same courses in Phase II, voluntarily participated in the research. During Phases I and III, there were 60 students in public administration and 62 students in teacher education. Our students are primarily working professionals. The courses in both disciplines are taught during the late afternoon or at night to accommodate the working professional. For instance, students in the public administration courses typically range in age from 25 to 40 and work in the public sector; those in the action research teacher education course are similar in age, but are teachers with about 5 to 8 years of classroom experience who are returning to secure their graduate degree. While we did not collect demographic data on the survey, we suggest that these data would be helpful in subsequent uses of the survey.

In addition, a one-page Informed Consent form was designed to inform students of their rights as participants in the study in that the process is voluntary and that securing their signatures simply signaled voluntary participation based on being informed of their rights as participants. Participants were also informed that they could withdraw at any time during the study and without penalty to their course grades, their status in any of the graduate programs, and their relationship with the schools or departments in which their programs were housed and/or the University or with the researchers (the authors), who were conducting the study. A human subjects expedited review approval was obtained from the University's Office of Research and Sponsored Programs (ORSP) to proceed with the research.

\section{Midterm Student Feedback Survey (MSF)}

After collaboration, we decided that the survey should ask students about key topics that often appear on the typical end-of-term course evaluation forms. Our survey was one page, double-sided, and included open-ended and closed-ended questions that included four main sections seeking the following information: 
specific feedback about knowledge of course expectations, course performance, course workload and teamwork (open and closed-ended questions), and general questions about what is working and what is not (open-ended questions).

\section{Procedures}

The University operates on a quarter or term system (11 weeks), and the surveys were initially distributed during the Winter and Fall terms over two academic years but within the same calendar year. To avoid any unintended effects so that the graduate students would not feel undue pressure to participate in the study, we administered the Informed Consent forms and surveys to each other's courses during the midpoint (approximately the fifth to sixth week) of each term during the Winter and Fall terms (Phases I and III; see Table 1 for the study timeline).

Table 1.

Timeline of Study of Midterm Student Feedback (MSF) Survey for Courses A, B, and $C$ (Phases $I-V)$

\begin{tabular}{|l|l|l|l|l|l|}
\hline Instructor & $\begin{array}{c}\text { Phase I } \\
\text { (Winter, } \\
\text { previous } \\
\text { academic } \\
\text { year) }\end{array}$ & $\begin{array}{c}\text { Phase II } \\
\text { (Winter, } \\
\text { previous } \\
\text { academic } \\
\text { year) }\end{array}$ & $\begin{array}{c}\text { Phase III } \\
\text { (Fall, subsequent } \\
\text { academic year/ } \\
\text { same calendar } \\
\text { year) }\end{array}$ & $\begin{array}{c}\text { Phase IV (Fall, } \\
\text { subsequent } \\
\text { academic year/ } \\
\text { same calendar } \\
\text { year) }\end{array}$ & Phase V \\
\hline 1 \\
$\mathrm{~N}=60$
\end{tabular}

\section{Mid-Course Corrections Implemented in Phase III (based on analysis during} Phase II)

In the following sections, we have chosen to use the first-person narrative to describe our study. In the public administration section, Dr. H. uses the pronoun I to indicate what she learned and changed based on the analysis of the surveys administered during Phase I. In the teacher education section, Dr. S. also uses the pronoun $I$ to describe what she learned and changed based on the analysis of the survey. In cases where we are referring to what we both learned, we continue to use the pronoun we. 
Public Administration Courses A \& B (Dr. H.) Based on feedback from the MSF in both of my courses, I modified the content of the lectures, the course syllabi, and feedback timing in the following term when I taught the course again or during Phase III. For example, before the study, in both courses, through class discussions, I consistently stressed the importance of the students' using the University's Writing Center as well as included the Writing Center's contact information and location on the course syllabi. The Phase I MSF survey indicated that students needed more assistance in writing. Therefore, in Phase III, I asked that Writing Center consultants visit each course at the beginning of each term to educate the students about the Center's resources.

For Course A, which was more theoretical in nature than Course B, I used three writing assignments, student-led presentations, and class discussions to determine students' understanding of the course material and ability to grapple with theoretical concepts related to the study about public organizations. I took class time before and after the completion of each writing assignment to explain the assignments as well as any themes that were discerned from students' papers. The MSF feedback indicated that students did not have an idea of how they were performing in the course and that the expectations were unclear. As a result, I made a change so that the first writing assignment was due the second week of the course so that students could see where their strengths and weaknesses lie and thus seek appropriate assistance from me and the Writing Center in a timely manner and before the end of the term. It is important to note that for this course, only the first writing assignment was affected since it was due before the midpoint of the term.

For Course B, I made two additional changes based on the feedback from the survey administered during Phase I and implemented during the Winter term or Phase III. First, a seasoned practitioner in public administration was brought in as a guest speaker before the middle of the term. And, second, students were concerned that in addition to the class discussions, they had no way of gauging their performance in the course even during the midterm since most of the written assignments followed the midpoint of the term. In response, I reinstituted a brief three-page critical analysis writing assignment. Articles were distributed for the analysis during the first class session of the course in Phase III, and the assignment was due the second week of the term. Students' performance on the assignment was also based on a previously distributed rubric. For each course, and during the initial class sessions of the respective terms (Winter and Fall), I explained the definitions of the levels of performance for the writing assignments (Excellent to Poor) as well as the four components upon which the writing assignments were based (content, critical analysis, organization, and writing quality). Further, to emphasize its importance, I continued to stress these writing expectations throughout the term. 
Teacher Education Program/Action Research Course C (Dr. S.) Course C was an Action Research proposal development course, the first of a two-course sequence where students design and implement an action research project in their classrooms. Students have 10 weeks to learn about action research and design a proposal. I made two changes during the next time I taught the course, Phase III, as a result of reviewing the MSF feedback from Phase I. First, the students wanted more examples of completed action research projects. I created a wiki, a web space for communicating with individuals and groups, for the course. I then found excellent examples from students' papers and, with their permission, posted them on the wiki. All students in the class were invited to participate on the wiki. Second, the students wanted more in-class time to discuss their projects and field their ideas with each other. To accommodate this request, I added 30-minute small group discussion sessions in three classes during the term. The next section describes the results from the MSF surveys in Phases I and III-Courses A, B, and C.

\section{RESULTS}

This section reports on the analysis of the MSF survey by comparing the surveys administered in the courses during Phase I (before the implementation of changes) and Phase III (after the implementation of the changes). We address the following research questions: First, "How does a different group of students in the same course respond to instructional changes based on the midterm survey results from a previous term?" and second, "What kind of midcourse corrections were made, and how do they align with effective instructional practices?

The data analyses for Courses A and B in public administration yielded overall improved results. Here, we summarize the results from different parts of the survey-expectations, performance, workload - that also include an analysis of the responses to open-ended questions both within each of the above sections and in the last three questions of the survey.

\section{Course A: Expectations}

All students reported that they had a clearer idea of what was expected in the course. Unlike the previous term (Winter), when only $69 \%$ reported that the course syllabus had made the difference, for the subsequent Fall term, 90\% of the participants reported that they found the course syllabus to be helpful in making the course expectations clear. In the short answer section, $60 \%$ of the responses indicated that the professor was clear about the course expectations; another $10 \%$ found the writing rubric to be helpful and that posing questions via Blackboard, a Course Management system, was also helpful.

Performance In comparison to the previous term (Winter), when only 15\% of the students said they were fully aware of how they were progressing in the course, during the subsequent Fall term, all students (100\%) had a clear idea of how they were performing in the course. In the short answer section, $90 \%$ of the 
Table 2.

Summary of Results of the Midterm Student Feedback (MSF) Survey for Three Graduate Courses (Public Administration and Education) Over Two Successive Terms (Phase V)

\begin{tabular}{|c|c|c|c|c|c|c|c|}
\hline \multirow{2}{*}{$\begin{array}{l}\text { Item } \\
\text { A. }\end{array}$} & \multirow[t]{2}{*}{ Question } & \multicolumn{2}{|c|}{$\begin{array}{l}\text { Course B - Public } \\
\text { Administration }\end{array}$} & \multicolumn{2}{|c|}{$\begin{array}{c}\text { Course B - Public } \\
\text { Administration }\end{array}$} & \multicolumn{2}{|c|}{$\begin{array}{l}\text { Course C - } \\
\text { Education }\end{array}$} \\
\hline & & $\begin{array}{c}\text { Time } 1 \\
\text { (Phase II) }\end{array}$ & $\begin{array}{c}\text { Time } 2 \\
\text { (Phase IV) }\end{array}$ & $\begin{array}{c}\text { Time } 1 \\
\text { (Phase II) }\end{array}$ & $\begin{array}{c}\text { Time } 2 \\
\text { (Phase IV) }\end{array}$ & $\begin{array}{c}\text { Time } 1 \\
\text { (Phase II) }\end{array}$ & $\begin{array}{c}\text { Time } 2 \\
\text { (Phase IV) }\end{array}$ \\
\hline & & $\mathrm{n}=12$ & $\mathrm{n}=16$ & $\mathrm{n}=14$ & $\mathrm{n}=18$ & $\mathrm{n}=33$ & $\mathrm{n}=30$ \\
\hline \multirow[t]{2}{*}{1.} & $\begin{array}{l}\text { Expectations } \\
\text { Clear idea } \\
\text { of expectations }\end{array}$ & $100 \%$ & $100 \%$ & $93 \%$ & $100 \%$ & $94 \%$ & $100 \%$ \\
\hline & $\begin{array}{l}\text { Comments: } \\
\text { What helped } \\
\text { know } \\
\text { expectations? }\end{array}$ & $\begin{array}{l}\text { Syllabus } \\
69 \% \\
\text { Prof. } \\
\text { explan. } \\
46 \%\end{array}$ & $\begin{array}{c}\text { Syllabus } \\
90 \% \\
\text { Prof. } \\
\text { explan. } \\
60 \%\end{array}$ & $\begin{array}{c}\text { Syllabus } \\
93 \%\end{array}$ & $\begin{array}{c}\text { Syllabus } \\
100 \% \\
\text { Rubric } \\
30 \% \\
\text { Prof. } \\
\text { explan. } \\
30 \%\end{array}$ & $\begin{array}{c}\text { Syllabus } \\
73 \% \\
\text { Rubrics } \\
67 \%\end{array}$ & $\begin{array}{c}\text { Syllabus } \\
77 \% \\
\text { Rubrics } \\
60 \%\end{array}$ \\
\hline 2. & $\begin{array}{l}\text { Performance } \\
\text { Clear idea of } \\
\text { how doing }\end{array}$ & $15 \%$ & $100 \%$ & $29 \%$ & $60 \%$ & $84 \%$ & $100 \%$ \\
\hline 3. & $\begin{array}{l}\text { Workload } \\
\text { Knowledge of } \\
\text { workload }\end{array}$ & $100 \%$ & $100 \%$ & $100 \%$ & $100 \%$ & $93 \%$ & $93 \%$ \\
\hline \multirow[t]{6}{*}{4.} & $\begin{array}{l}\text { Assignment } \\
\text { Instructions } \\
\text { Combined } \\
\text { well-explained } \\
\text { \& explained } \\
\text { categories }\end{array}$ & & & & & & \\
\hline & $\begin{array}{l}\text { Written } \\
\text { assignments }\end{array}$ & $93 \%$ & $100 \%$ & $93 \%$ & $70 \%$ & $86 \%$ & $97 \%$ \\
\hline & Class discussions & $100 \%$ & $100 \%$ & $100 \%$ & $90 \%$ & $90 \%$ & $96 \%$ \\
\hline & Class case studies & $77 \%$ & $80 \%$ & $86 \%$ & $80 \%$ & NA & NA \\
\hline & Team case studies & NA & NA & $94 \%$ & $80 \%$ & NA & NA \\
\hline & Team projects & NA & NA & $100 \%$ & $100 \%$ & NA & NA \\
\hline 5. & Teamwork & NA & NA & $100 \%$ & $80 \%$ & $90 \%$ & $90 \%$ \\
\hline
\end{tabular}

students believed that the feedback on their first writing assignment helped them to gauge their performance; 30\% reported that they received positive feedback about class participation; and 10\% each reported that they had received feedback 
based on their individual student-led presentations, understood and participated in class discussions, and were able to discern their performance in the course from the questions posed with periodic acknowledgement from me, the instructor, on how well they were doing in the course.

Workload All students (100\%) reported that they were clear about the expectations for successful completion of the course in Phase I. Of the comments made, $40 \%$ found that the course syllabus was clear, and a few (each item was $10 \%$ of the total comments) noted that the following clarified the course workload: class discussions, the three writing assignments where the paper expectations were clearly outlined, the writing rubric. An improved 100\% reported that the writing assignments were either well or adequately explained. However, unlike the previous term, $100 \%$ stated that the class discussions were either well or adequately explained. Forty percent of the respondents chose not to comment in this section, although $10 \%$ of them found the following: instructions for the written assignments were brief and opened ended; I, the instructor, was very knowledgeable, but students wanted more information about the theoretical concepts, believed that they learned the most from the class discussions, and found the assigned student-led presentations to be very interesting while others loved the assigned articles for this activity.

General Questions Unlike the previous Winter term, fewer students criticized what was not working in the course (20\% vs. $10 \%)$. However, a small number $(10 \%)$ reported the following: While they believed that the class discussions were great, they thought that more would have been gained as they found tolerating some classmates' opinions to be difficult because they viewed those students as overly enthusiastic. Some students stated that although the course was a little behind, it did not adversely affect the flow of the course. Others would have liked more lectures by the instructor to fill in material that was not presented in the studentled discussions, whereas others found accessing the textbook on reserve in the library to be difficult. Overall, students were happy with the course, although they considered that some of the student-led presentations were better than others. Yet, they believed that this was an inherent part of the process. Others believed that the student-led discussions should be limited to 10 minutes; while some found the reading to be overwhelming for those who worked full-time. While $30 \%$ of the students reported that they were satisfied with the course, another 30\% said they would have liked more facilitated discussions by the instructor. Ten percent each stated that they would have liked more lectures before the student-led presentations and would like to have engaged in group or team work, though the course was not designed for this type of exercise. Overall, the course was well received. Some students found the course to be exemplary while others stated that they were learning a great deal. Likewise, many reported that the course was exactly what they expected at the graduate level. 
Course B generated far more open-ended feedback from respondents, due to the nature of the course and the associated workload. Unlike Course A, Course B required significantly greater student-to-student interaction, teamwork, instructordirected lectures, case studies, and almost weekly individual and team assignments beyond the required weekly course reading. These activities were integral elements of the course. Additionally, unlike Course A, Course B was designed to be balanced in theory and practice.

\section{Course B: Expectations}

All students during the Fall (second) term (100\% vs. 93\% during the previous Winter term) found that the course expectations were clear. All students attributed the clarity of the course expectations to the course syllabus, $30 \%$ to the clearly stated rubric, the instructor's establishment of clear guidelines at the outset; but $10 \%$ were still unclear as to what constituted an "A" performance in the course. Ten percent of the students liked that the instructor employed Blackboard in conjunction with other media for communication; gained clarity about course assignments, for instance, by meeting outside of the classroom with the instruc tor; and some were already clear about the course expectations during the first class session.

Performance More students (60\%) had a clear idea of how they were doing in the course (vs. 29\%), but 40\% were still unclear about their performance. Eighty percent reported that they knew how they were performing; however, some commented that they would have preferred to have the instructor provide feedback as typed notes, because it was difficult to decipher the penpersonship (penmanship). Ten percent of the participants found that the instructor was very detailed in grading, that they could participate in class discussions, and that the feedback on the first writing assignment was an excellent gauge of their performance.

Workload All students (100\%) reported that they were fully apprised of the expected workload for successful completion of the course. Twenty percent of those who commented said, though, that the high expectations for the course were difficult; $20 \%$ stated that while at a glance the workload might have appeared to be similar to other courses in the program, the required teamwork was time consuming. Ten percent each complained that it was difficult to have to visit the campus an additional day of the week because of the required book that was on reserve at the library, believed that there were too many overlapping assignments, reported that it took too long to establish Blackboard accounts for communication with the instructor and each other, and would have preferred individual assignments rather than teamwork assignments. It is important to note that the Fall term represented the first time that Blackboard was fully launched as a new medium for communicating with students. The University had recently transferred its system from WebCT, a previously employed system for the same purpose to Blackboard. 
Both the students and I, the instructor, were experiencing growing pains associated with adjusting to this new hybrid online system. And while 10\%, respectively, complained that it was difficult to track the time on the course syllabus because of the time lag and suggested that some of the areas listed should be dropped, others reported that they found the course syllabus to be very explicit about the expectations of the course. Additionally, my consistent repetition of these expectations during the term reinforced the students' understanding of them.

For instructions regarding the course expectations and assignments, given course goals, $70 \%$ found that the written assignments were either well or adequately explained (vs. 93\%); the team case studies were $80 \%$ well or adequately explained. Twenty percent needed more information (vs. $84 \%$ and $7 \%$ ); the team project was well to adequately explained ( $100 \%$ vs. $92 \%)$; in-class case studies were well to adequately explained at $86 \%$ with $7 \%$ needing more information (vs. $80 \%$ and $20 \%$ ); and in-class discussions were well to adequately explained at a rate of $90 \%$ with $10 \%$ needing more information ( $100 \%$ and $0 \%$ ). While $60 \%$ of the students chose not to comment, of those who did, another $10 \%$ reported that the instructor had done an extensive amount of work to ensure that students understood the course assignments. To the students, this work was by far more than they had ever done in other graduate courses of the program. Some students did not see the relevance of the case studies to the course, and some wanted more explanation for the first assignment. Others believed that the instructor should focus less on time and more on the class discussions, because doing so made students feel as if the instructor were trying to meet benchmarks.

Regarding teamwork, compared to the previous term (100\%), 90\% of the students believed that they had an opportunity to showcase their own contributions in their respective teams. For these students, $20 \%$ each did so through team discussions, satisfying project timeline and content, participation in the team process, and playing a leadership role. Others (10\%) stated that they had participated in their teams through the writing and preparation of the team proposal; took the lead in electronic communiques with team members in such areas as research, offering suggestions, brainstorming, assistance with meeting, conversations, and facilitating the team project; and believed that they did so equally as team members.

General Questions When asked what was "working" in the course, at least $50 \%$ reported that the lectures were good; the subject matters of discussions were great $(20 \%)$; class discussions were excellent, and they had much opportunity to participate (20\%); they liked the instructor's lecturing style and the facilitation of student participation by allowing no student to dominate class discussions (20\%); the textbooks were good (20\%); the instructor was only one of few who did not use PowerPoint as the sole method of instruction; and the instructor was very skilled in her craft and passionate about the subject matter (10\%). Fifty percent of those who commented found that the strict adherence to the time caused undue pressure in the classroom; 20\% wanted copies of the PowerPoint 
slides via Blackboard; $10 \%$, respectively, had varying opinions that ranged from still being unclear about their respective performance to disliking the idea of having a book on reserve in the library. To the question on what students would like to have seen more of in the course, a few respondents were equally opinionated. Ten percent each wanted more group activities, would have found it helpful at the end of each class if the instructor identified the reading assignments for future class sessions, said case study discussions were hampered by time constraints, considered the sometimes calling on of students to be too much like law school, understood why certain decisions are made in the legal process, and needed more practical application. Therefore, from all indications, although both public administration courses were fundamentally different in design and content, the midcourse corrections implemented in each course resulted in marked improvements with each administration of the MSF survey (from Time 1-Phases I and III to Time 2-Phases II and IV; see Table 2). Consequently, I received similar results for the end-of-term evaluations.

The data analysis for Course C (teacher educations/action research) showed that the direction of change from Phase I to Phase III was either positive or remained the same. In addition, the percentages indicated that there was a positive regard for the course (>60\%). The instructor had been teaching this course for over 12 years. The results for the end-of-term evaluations were equally positive.

\section{Course C: Expectations}

I was able to boost the results for this category following the correction based on the MSF administered in Phase I and implemented in Phase III. As a tenured, experienced instructor, I found many of the scores across all sections of the survey were initially quite high. However, I found several items that were quite informative and led to significant improvement in the course. Specific details of what helped students learn the expectations showed up in the written materials as a result of the syllabus and the rubrics. There were seven rubrics for the seven assignments in this course. I had refined the language of these assignments over the years.

Performance The percentages on student perception of their performance changed from $84 \%$ to $100 \%$. The open-ended comments in this category pointed to the feedback on the papers and the rubrics as central to understanding how well students were doing. I ensured that their papers were returned to the students the very next week following the submission of their assignments. Their problem statement was due the second week of class and submitted on Blackboard, the Course Management System. I gave them detailed, specific feedback on this assignment by the third week of the class. Students were given the opportunity to resubmit all of their papers (literature review, methods) up to three times for feedback before they combined the papers into the final proposal. 
Workload Ninety-three percent of the students were confident that they knew the amount of work that was expected of them in the course in Phase I. This improved to $100 \%$ in Phase III. While this result was significant, 6\% (2) of the students mentioned in the comments that the course was a lot of work. The drafts of the problem statement, literature review, and methods were due during the first 5 weeks of the course. Doing so provided the students time to complete first drafts of all three assignments for submission by the fifth week of the term. Further, following the initial submission of each assignment, students could resubmit the assignments for additional feedback.

Assignment Instructions Students seemed to have a good understanding of the assignment instructions. However, when I noticed the overall 86\% results on written assignments for the course in Phase I, I spent more time reviewing the rubrics assigned for each of the three primary course papers in Phase III. This review seemed to have affected how the students responded to the written assignments.

General Questions Students noted that the syllabus, rubrics, and resubmissions of each assignment work quite well for them. Some students even appreciated the group work. Over both terms, Phase I and Phase III, the two things that were most salient and provided marked improvement from one term (Winter) to the other (Fall) were the "sample projects" and "time to talk to peers about projects." Given the course corrections from Phase I to Phase III, students in Phase III appreciated the opportunity to see examples of other action research projects as well as have more time to discuss their project with their peers.

\section{ConClusion}

The preceding study on midterm student feedback (MSF) reinforced the value of employing this tool to facilitate not only improved student learning outcomes but also enhanced teaching effectiveness. This study supported previous evidence that while the end-of-course evaluations can yield critical information for assisting faculty in improving course design and content, they do little for current students. Therefore, the timely correction of students' concerns through the implementation of midcourse corrections - in this case, during the midpoint of an 11-week term-affords both the instructor and students the opportunity to change the direction of the teaching and learning of the course for the improvement of both constituents. In turn, instructors are viewed as receptive to students' learning needs, students may act in kind by rewarding instructors with more favorable end-of-course evaluations, and instructors become more adept at teaching. Yet, while this study demonstrated the utility of midterm student feedback, it also revealed some shortcomings_-among them the challenge of implementing the MSF tool during a term system. 


\section{Limitations}

First, the most salient limitation of this study is the generalization of its findings over the successive terms to different samples of students. This decision was a function of the abbreviated duration of the 11-week term; although the MSF survey was considered an effective tool, employing it during the quarter system may have generated results less robust than what might have been possible if it were employed under a semester system.

Second, given the above, can the correlations between midcourse corrections made during one term with one sample of students be directly attributed to improvements in another term with a different sample of students? In essence, the correlation of results between the two terms might not necessarily have meant causality; instead, the results could have been due to other, unknown moderating variables. Therefore, making the appropriate midcourse corrections during the same term and with the same sample of students in each course might have yielded different results.

Third, while the MSF surveys were administered within the same calendar year over two terms, not during the same academic year, this timing was primarily a condition of when the courses were scheduled to be taught next. Consequently, we held little to no influence over course offerings, because such schedules are dictated more or less by the levels of enrollment for each course as well as by the administrative hierarchy of the respective schools.

Fourth, the MSF survey was administered only to required courses in each program. Thus, given the available research, would different results have been produced if this strategy were applied to elective courses?

Fifth, because the primary focus of this study was to acquire as much student feedback as possible in an effort to increase student learning outcomes, of utmost concern was designing a tool that could quickly and effectively encapsulate this information. As a result, the length of the MSF survey was limited to a one-page, double-sided tool. Nevertheless, while it would have been as important to garner such demographic data as age, race, and whether students were pursuing their academic degrees on either a part-time or full-time basis, we found that securing this material was impractical.

\section{Strengths}

We believe that despite the obvious limitations of this study, the benefits of the MSF survey appear to far outweigh the drawbacks in generating some novel and robust results. Foremost is the instrumentality of the tool in achieving marked improvements in overall student learning outcomes, even if the changes were made during a subsequent term when the same course is offered and not during the term when the MSF survey was administered. In effect, the MSF survey is an equally effective tool that is based on the feedback of previous samples of students, though those results were not directly applied to the same samples of students. 
Although the abbreviated period of the quarter term can make instituting midcourse corrections based on the MSF survey to be an especially challenging calibration for faculty, its timely implementation, even during a later term for the same course, can still yield positive outcomes for both students and faculty.

We also believe that, to some degree, by employing the MSF survey, and during a quarter system, we were able to address some of the gnawing criticisms and frustrations with the often used end-of-term course evaluations as being largely ineffective. By instituting the MSF survey that is strictly based on students' input and is the instrument for carrying out midcourse corrections, it in turn served as a conduit for improving student learning outcomes and then becomes a student-centered tool in itself. Further, not only does the MSF survey serve as a modality for continuing to refine courses given student feedback, but by making the necessary midcourse corrections at the midpoint of a course for the timely redirection of student learning, it increased the probability of more favorable end-of-term course evaluations for faculty. We also discovered some interesting and unexpected findings in the process of conducting this study. We discovered not only the benefits of interdisciplinary and cross-campus collaboration, and the lessons learned from doing so, but also the importance of mentorship by having a junior and untenured faculty reap the advantages of working with and gaining the expertise of a more seasoned and tenured senior faculty. Too, and in keeping with the literature, we found that embedded in this latter finding was the generally negative end-of-course evaluations that quite often may serve to undermine and sabotage the well intentioned efforts of particularly underrepresented minority and female faculty to teach courses that are overwhelmingly attended by majority students. Thus an unintentional consequence of our study was to appreciate the importance for such faculty to more quickly assess the tenor of the student body of each course as one way to mitigate students' potentially biased perceptions that are unrelated to faculty teaching competence.

\section{Implications for Future Research}

In light of the benefits derived and even the limitations of using the midterm student feedback survey within a term system, it would be interesting to determine its utility at the undergraduate level for public administration and education programs as well as other programs. Particularly for students and junior faculty, challenges to learning could be identified at the earliest possible stages of a course in order to mitigate frustration and increase the likelihood of producing more positive learning experiences for faculty and students alike. As well, future MSF tools could be designed to capture such demographic data as age, race and/ethnicity, and whether students are pursuing their academic endeavors on a part-time or full-time basis. 


\section{REFERENCES}

Abrami, P., d'Apollina, S., \& Rosenfield, S. (2007). The dimensionality of instruction: What we know and what we do not. In R. P. Perry \& J. C. Smart (Eds.), The scholarship of teaching and learning in higher education: An evidence-based perspective (pp. 385-456). The Netherlands: Dordrecht.

Algozzine, B., Beattie, J., Bray, M., Flowers, C., Gretes, J., Howley, et al. (2001). Student evaluation of college teaching: A practice in search of principles. College Teaching, 52(4), 134-141.

Armstrong, J. S. (1998). Are student ratings of instruction useful? American Psychologist, 53(11), $1223-1224$

Austin, D., \& Austin, J. (2002, April 7-9). Using Blackboard to survey students at midterm. In Teaching, Learning, and Technology: The Connected Classroom. Proceedings of the Annual Mid-South Instructional Technology Conference (7th), Murfreesboro, TN.

Baker, G. P. (1992). Incentive contracts and performance measurement. Journal of Political Economy, 100(3), 598-614.

Ballantyne, C. (2000, November). Why survey online? A practical look at issues in the use of the Internet for surveys in higher education. Paper presented at the annual conference of the American Evaluation Association in Honolulu, HI.

Basow, S. A. (1998). Student evaluations: The role of gender bias and teaching roles. In L. H. Collins, J. C. Chrisler, \& K. Quina (Eds.), Career strategies for women in academe: Arming Athena (pp. 135-156). Thousand Oaks, CA: Sage.

Campbell, H. E., Steiner, S., \& Gerdes, K. (2005). Student evaluations of teaching: How you teach and who you are. Journal of Public Affairs Education, 11(3), 211-231.

Carrell, S. E., \& West, J. E. (2010). Does professor quality matter? Evidence from random assignment of students to professors. Journal of Political Economy, 118(3), 409-432.

Centra, J. A., \& Gaubatz, N. B. (2000). Is there gender bias in student evaluations of teaching? Journal of Higher Education, 71(1), 17-33.

Chen, W., \& Chen, W. (2010, October). Surprises learned from course evaluations. Research in Higher Education Journal, 9, 1-9.

Clayson, D. E. (2009). Student evaluations of teaching: Are they related to what student learns? A meta-analysis and review of the literature. Journal of Marketing Education, 31(1), 16-30.

Clayson, D. E., \& Haley, D. A. (2011). Are students telling us the truth? A critical look at the student evaluation of teaching. Marketing Education Review, 21(2), 103-114.

Cohen, P. A. (1980). Effectiveness of student-rating feedback for improving college instruction: A meta-analysis. Research in Higher Education, 13, 321-341.

Davis Bullock, C. (2003). Online collection of midterm student feedback. New Directions for Teaching and Learning, 96, 95-102.

Diamond, M. R. (2004). The usefulness of structured mid-term feedback as a catalyst for change in higher education classes. Active Learning in Higher Education, 5(3), 217-231. 


\section{G. L. A. Harris \& D. D. Stevens}

Foote, D. A., Harmon, S. K., \& Mayo, D. T. (2003). The impacts of instructional style and gender role attitude on students' evaluation of faculty. Marketing Education Review, 13(2), 9-19.

Friedlander, J. (1978). Student perception on the effectiveness of midterm feedback to modify college instruction. Journal of Educational Research, 71(3), 140-143.

Gallagher, T. J. (2000). Embracing student evaluations of teaching: A case study. Teaching Sociology, $28(2), 140-147$.

Germain, M., \& Scandura, T. A. (2005). Grade inflation and student individual differences as systematic bias in faculty evaluations. Journal of Instructional Psychology, 32(1), 58-67.

Giles, O., \& Pascoe, R. (2004). Student evaluations; fact or fiction? Hawke’s Bay, New Zealand: Eastern Institute of Technology, 272-275.

Gray, M., \& Bergman, B. R. (2003, September-October). Student teaching evaluation: Inaccurate, demeaning, misused. Academe, 44-46.

Hattie, J., \& Timperley, H. (2007). The power of feedback. Review of Educational Research, 77(1), 81-112.

Heine, P., \& Maddox, N. (2009). Student perceptions of the faculty course evaluations process: An exploratory study of gender and class differences. Research in Higher Education Journal, 3, 1-10.

Hobson, S. M., \& Talbot, D. M. (2001). Understanding student evaluations: What all faculty should know. College Teaching, 49(1), 26-31.

Holt, M. E., \& Moore, A. B. (1992). Checking halfway: The value of midterm course evaluation. Evaluation Practice, 13(1), 47-50.

Johnson, V. E. (2003). Grade inflation: A crisis in college education. New York: Springer.

Kember, D., Leung, D. Y. P., \& Kwan, K. P. (2002). Does the use of student feedback questionnaires improve the overall quality of teaching? Assessment and Evaluation in Higher Education, 27(5), $411-425$.

Keutzer, C. S. (1993). Midterm evaluation of teaching provides helpful feedback to instructors. Teaching Psychology, 20(4), 238-240.

Kulik, J. (2001). Student ratings: Validity, utility and controversy. In M. Theall, P. Abrami, \& L. Mets (Eds.), The student ratings debate: Are they valid? How can we best use them? (New Directions for Institutional Research, 109, 9-25). San Francisco: Jossey-Bass.

Lang, J. W. B., \& Kersting, M. (2006). Regular feedback from student ratings of instruction: Do college teachers improve their ratings in the long run? Instructional Science, 35, 187-205.

Langbein, L. (1994). The validity of student evaluations of teaching. Political Science and Politics, 27(3), 545-553.

. (2005). Management by results: Student evaluation of faculty teaching and the mismeasurement of performance. Paper presented at the Annual Meeting of Public Choice, New Orleans, LA.

Marsh, H. W., \& Hocevar, D. (1991). Students' evaluations of teaching effectiveness: The stability of mean ratings of the same teachers over a 13-year period. Teaching and Teacher Education, 7 , 303-314. 
Marsh, H. W., \& Roche, L. A. (1997). Making students' evaluations of teaching effectiveness effective: The critical issues of validity, bias, and utility. American Psychologist, 52(11), 1187-1197.

McKeachie, W. J. (1997). Student ratings. American Psychologist, 52(11), 1218-1225.

Moore, P. (2009). Why we should measure student learning: A glossary of collegiate corruption. In R. E. Flinn \& D. L. Crumbly (Eds.), Measure learning rather than satisfaction in higher education. Sarasota, FL: American Accounting Association.

Murkison, G., \& Stapleton, R. J. (2001). Optimizing the fairness of student evaluations: A study of correlations between instructor excellence, study production, learning production, and expected grades. Journal of Management Education, 25(3), 269-291.

Murray, H. G. (1987). Acquiring student feedback that improves instruction. In M. G. Weimer (Ed.), Teaching large classes well (New Directions for Teaching and Learning, 32, 85-96). San Francisco. CA: Jossey-Bass.

Overall, J. U., \& Marsh, H. W. (1979). Midterm feedback from student: Its relationship to instructional improvement and students' cognitive and affective outcomes. Journal of Educational Psychology, $71(6), 856-865$.

Richardson, J. T. E. (2005). Instruments for obtaining student feedback: A review of the literature. Assessment and Evaluation in Higher Education, 30(4), 387-415.

Senior, B. A. (2000). Student teaching evaluations: Options and concerns. Journal of Construction Education, 5(1), 20-29.

Sheehan, K. B. (2001). Email survey response rates: A review. Journal of Computer Mediated Communication, 6(2), 1-16.

Slocombe, T., Miller, D., \& Hite, N. (2011). A survey of student perspectives toward faculty evaluations. American Journal of Business Education, 4(7), 51-57.

Sojka, J., Gupta, A. K., \& Deeter-Schmelz, D. R. (2002). Student and faculty perceptions of student evaluations of teaching: A study of similarities and differences. College Teaching, 50(2), 44-49.

Thorton, B., Adams, M., \& Sppehri, M. (2010. The impact of students' expectations of grades and perceptions of course difficulty, workload, and pace on faculty evaluations. Contemporary Issues in Education Research, 3(12), 1-5.

Whittington, L. A. (2001). Detecting good teaching. Journal of Public Administration Education, 7(1), 5-8.

Wolfer, T. A., \& McKnown Johnson, M. (2003). Re-evaluating student evaluation of teaching: The teaching evaluation form. Journal of Social Work Education, 39(1), 111-121.

Yao, Y., \& Grady, M. L. (2006). How do faculty make formative use of student evaluation feedback? A multiple case study. Journal of Evaluation Education, 18, 107-126. 
G. L. A. Harris is an associate professor of Public Administration in the Mark O. Hatfield School of Government at Portland State University. She received her $\mathrm{PhD}$ in Public Administration with concentration in Public Management from Rutgers University. Her research interests revolve around the theme of equity by examining such issues as civil rights (affirmative action), the military (recruiting and retention patterns, gender, race, and health care), gender equity (the military and the academy) and health care (the military, veterans and cultural competence). Dr. Harris has published in a number of journals including Administration and Society, Public Administration Review, and the Journal of Military Studies, to name a few. She co-edited Women of Color in Leadership: Taking Their Rightful Place (2010) with Richard Greggory Johnson III and has a forthcoming book, Living Legends and Full Agency: Implications for Repealing the Combat Exclusion Policy. Dr. Harris is also a commissioned officer in the U.S. Air Force Reserve and formerly served on active duty in the U.S. Air Force.

Dannelle D. Stevens is a full professor of Curriculum and Instruction in the Graduate School of Education at Portland State University. She taught in the public school system for 14 years across four school districts within three states. She received her doctorate in Educational Psychology from Michigan State. Her first book, co-edited with Joanne Cooper, Tenure in the Sacred Grove: Issues and Strategies for Women and Minorities (SUNY Press, 2002), was written to help faculty women and minorities negotiate the path to tenure. Introduction to Rubrics, now in its second edition and co-authored with Antonia J. Levi, and Journal Keeping, co-authored with Joanne Cooper, are published by Stylus Publishing. In addition to teaching classes, she has taken on leadership positions in the department and campus-wide. In the Curriculum and Instruction Department, Dr. Stevens leads teacher licensure cohorts and coordinates the MA/MS program for experienced teachers. For the university at large, she works within the Center for Academic Excellence as faculty-in-residence for assessment and is chair of the Institutional Assessment Council. 